\title{
Endoscopy in surgery
}

\author{
Ahmet Serdar Karaca(D), M. Mahir Özmen(D), Ahmet Çınar Yastı(D), Seher Demirer(D) \\ On Behalf of the Initiative of the Board on Directors of the Turkish Surgical Society
}

\begin{abstract}
In the last 20 years, there have been important developments in endoscopy. Initially, endoscopy was developed and used as a diagnostic tool. As new technology developed, these devices also became the basis for therapeutic maneuvers. In recent years, flexible endoscopes have been used to perform procedures replacing traditional surgical approaches. Examples of this field are transanal minimally invasive surgery, natural orifice transluminal endoscopic surgery, endoscopic metabolic surgery and third space endoscopies. Throughout history, surgeons have played a vital role in the design and development of endoscopic techniques, procedures, and equipment. Surgeons continue to lead the advancement of endoscopy, make important contributions, and serve as role models for innovation.
\end{abstract}

Keywords: Endoscopy, percutaneous endoscopic gastrostomy (PEG), endoscopic retrograde cholangiopancreatography (ERCP), endoscopic ultrasound (EUS), Lumen-attaching metal stents (LAMS)

Cite this article as: Karaca AS, Özmen MM, Yastı AÇ, Demirer S. Endoscopy in surgery. Turk J Surg 2021; 37 (2): 83-86.

\section{Corresponding Author}

Ahmet Serdar Karaca

E-mail: karacaahmetserdar@gmail.com

Received: 08.03 .2021

Accepted: 19.04.2021

Available Online Date: 30.06 .2021

O Copyright 2021 by Turkish Surgical Society Available online at www.turkjsurg.com

DOI: 10.47717/turkjsurg.2021.000000576

\section{INTRODUCTION}

The desire to examine the organs of the human body through natural holes is not new (1). The history of endoscopy goes back to the time when Hippocrates (460$375 \mathrm{BC}$ ) described the use of a rectal speculum similar to those currently used. Similar instruments had been described in Roman medicine, including a three-bladed vaginal speculum found in the ruins of Pompeii. Albulassim (912) reflected light with a mirror to see body cavities. Venezuelan Guilio Cesare Aranzi used the camera obscura [1587] to focus a beam of light to allow viewing the nasal cavity. Bozzini [1806] used the Lichtleiter, or light conductor, at the Medical Faculty in Vienna. Using principles illustrated in Bozzini's Lichtleiter, Segalas [1826] developed the speculum urethro-cyst, which uses two small candles and a conical mirror to focus light on the bladder, allowing visual inspection. In 1853 Antonin J. Desormeaux adapted a kerosene lamp that burns alcohol and turpentine held in a chamber at the base of the handle to create a narrower beam of light, which is thought to provide a brighter illumination of the area to be visualized. Desormeaux was the first physician to use Lichtleiter in a patient and the first physician to use the term Endoscopy, as well as endoscopic instruments for diagnosis and treatment (2). Kussmual performed the first successful gastroscopy in 1886. Leiter developed an esophagoscope with a mignon lamp in 1881, and Chevalier Jackson, an otolaryngologist, first used the bronchoesophagoscope to remove foreign bodies from humans in 1907. In 1937, Rudolf Schindler developed the semi-flexible endoscope, and in 1968 McCune, Shorb and Moscovitz described the first successful endoscopic cannulation of the pancreas and bile ducts, creating the initiative for endoscopic retrograde cholangiopancreatography (ERCP). Wolf and Shinya performed the first colon polypectomy using a flexible endoscope in 1974. Ponsky and Gauderer revolutionized the nutritional care of patients by describing percutaneous endoscopic gastrostomy (PEG) in 1980, and Steigmann and Goff described endoscopic varicose band ligation in 1988 (Table 1).

In addition to the founding role played by many leading surgeons in establishing endoscopy as a diagnostic and therapeutic approach to patient care, surgical 
Table 1. Endoscopy is part of our historical surgical heritage Endoscopic procedures developed by surgeons

\begin{tabular}{|l|c|}
\hline Procedure & Surgeon \\
\hline Colonoscopy & Turell \\
\hline Control of hemorrhage & Gaisford, Sugawa \\
\hline Polypectomy & Shinya, Wolf \\
\hline ERCP & McCune, Shorb \\
\hline Variceal banding & Steigman \\
\hline PEG & Ponsky, Gauderer \\
\hline Biliary stenting & Sohendra \\
\hline $\begin{array}{l}\text { ERCP: Endoscopic retrograde cholangiopancreatography, PEG: Percutaneous } \\
\text { endoscopic gastrostomy. }\end{array}$ \\
\hline
\end{tabular}

endoscopists are an important element of the healthcare workforce (3). The burden of screening procedures alone has already far exceeded the labor supply in most areas, and without the contribution of surgeons skilled in performing screening, therapeutic, curative and palliative endoscopic procedures, patient access to appropriate care will be severely limited. Surgeons must perform endoscopy to benefit their patients and advance their expertise.

A study comparing the practice patterns of rural and urban surgeons showed that both groups performed endoscopy as a routine part of their practice, but rural surgeons performed significantly more endoscopy (4). A prospective analysis of 3.525 endoscopic procedures performed by surgeons, published in Surgical Endoscopy, showed that surgeons performed these examinations with excellent results. No complications were reported in 3.447 patients (97.8\%) (5). A prospective analysis of 13.580 colonoscopies performed by surgeons showed excellent results, with a $0.2 \%$ complication rate and a $0.007 \%$ perforation rate (6). Lee et al. Have demonstrated equivalent adenoma detection rates among surgeons and gastroenterologists, and contributed to the literature demonstrating that surgeon endoscopists are mindful specialists with excellent results serving the needs of their patients (7).

\section{Endoscopy Training}

Endoscopy is one of the main tools of the practicing surgeon. General surgeons in Europe have established scientific associations and published scientific journals in order to standardize and advance the education and practices related to endoscopy, to disseminate them among their professional mothers and to share their results (Ex: European Association for Endoscopic Surgery: EAES). Likewise, similar associations have been established in the USA (Ex: Society of American Gastrointestinal and Endoscopic Surgeons: SAGES). EAES and SAGES have jointly published the journal "Surgical Endoscopy" as the official scientific journal since 1986. The American Board of Surgery recognized the increasing role of endoscopy in surgical practice and in 1985 recommended that at least 29 endoscopic cases be performed by graduate surgical residents. This was based on the goal of ensuring that all surgeons are exposed to endoscopic techniques. This requirement was later changed in response to the argument that this experience set the threshold too low for a graduate assistant to be proficient in endoscopy. Effective for residents graduating in June 2009 (8), the requirement has been changed to include 35 flexible endoscopy and 50 colonoscopy as new minimum thresholds.

The American Society of Gastrointestinal and Endoscopic Surgeons (SAGES), a professional community based on the principles of performing endoscopy by the surgeon, has developed the Fundamentals of Endoscopic Surgery program as a competency-based platform for endoscopy education. This curriculum is a solid collection of didactic materials and is available to anyone who wishes to learn the practice of endoscopy, regardless of specialty, and is included in the general surgery residency curriculum.

The Turkish Ministry of Health Medical Specialization Committee established curriculum preparation commissions for all major and minor branches in 2010 and organized a workshop on 15-17 January 2010 with the participation of 94 specialization commissions. Afterwards, the commissions that continued their studies entered the curriculum they developed into the Expert Board in Medicine Curriculum Formation and Standard Determination System Database. Endoscopy education was widely included in the curriculum developed by the General Surgery Commission and agreed upon unanimously. The endoscopy training curriculum recommended by this commission and the surgical endoscopy section in the General Surgery Specialization Training Core Training Program published by the Turkish Society of Surgery in 2006 almost completely overlap. European Union of Medical Specialists (UEMS) rearranged all the curriculum, definitions, justifications of the program, compulsory knowledge and skills related to general surgery with the guidelines it published on 29 October 2010. The necessary knowledge and skills related to endoscopy during surgical training have been put in the form that has been included in this program for many years. In the section of these guidelines where the responsibility areas of general surgery are defined, "therapeutic and diagnostic endoscopy of the digestive tract" is especially emphasized among the primary areas of responsibility. A special section is reserved for endoscopy in the European Surgical Qualification Board's (UEMS, Surgery Section, Board of General Surgery) directive on "mandatory skills during surgical training".

The issue of how endoscopy training should be given during the training of surgical assistants has been researched with different aspects for many years. In all studies, it has been emphasized that endoscopy is absolutely necessary for the surgeon, but that this education should be given in accordance with technologi- 
cal developments. In the last decade, with the development of techniques in which endoscopy is used as a tool (NOTES: natural orifice transluminal endoscopic surgery, robotic surgery, etc.), it has been suggested that endoscopy education should be given in this direction in many studies, especially in America and Europe. That is, the surgical assistant will not only have basic endoscopy training, but will have to learn enough to use endoscopy as a tool to be able to perform advanced surgical operations. The issue should also be carefully evaluated in terms of public health. Digestive system cancers are increasing day by day all over the world. Early diagnosis is life-saving in these diseases, and therefore, the number of people who will perform screening endoscopy should be increased. Countries such as England, America and Australia saw that the number of available physicians would not be sufficient to solve this problem and started to have trained nurses perform endoscopic procedures. Considering the results of preliminary research on the work of nurses in the practice of endoscopy, this practice has begun to become widespread. In the light of these scientific data, the British government encouraged and authorized nurses to perform endoscopy. Studies conducted after the issue had become a national policy revealed that nurses performed endoscopy as successfully and safely as doctors. Today, around 350 nurses, in addition to general surgeons and internal medicine specialists, serve the public by performing endoscopy every day in England. On the other hand, the USA and Japan have begun to authorize trained general practitioners for screening gastroscopy/colonoscopy in order to find a solution to the problem. It has been determined by scientific research that the endoscopies performed by general practitioners are as safe and successful as necessary.

Surgeons frequently use endoscopy in the preoperative, intraoperative and postoperative care of their patients. In the preoperative period, endoscopy is mainly used to diagnose conditions and localize lesions, plan surgery and provide nutritional support (9). Intraoperative endoscopy is used to localize lesions, evaluate the anatomical outcome of surgery, and test anastomotic integrity during foregut and colorectal reconstructive procedures. For instance, the image provided during fundoplication, esophageal myotomy and bariatric surgery helps the rest of the operation. Postoperative endoscopy fulfills an important clinical role in the follow-up of patients with premalignant and malignant conditions such as Barrett's esophagus, colon polyps, and post-resection follow-up needs for three examples, esophagus, stomach and colon cancer. Flexible endoscopy also plays an important role in the management of operative complications, including marginal ulcers, anastomotic leaks, fistulas, and retained biliary stones.

\section{The Future of Surgery and Endoscopy}

Thirty years ago, the advent of operative laparoscopy marked the beginning of a new era in general surgery. Surgical procedures have changed altogether and new procedures have been developed by taking advantage of the strengths of the laparoscopic platform. Hospital dynamics deteriorated as patients who stayed in the hospital for a week now receive outpatient treatment. Robotics has furthered these advances in some areas.

The future of surgery will be affected by the future of surgeon-performed endoscopy. The limits of third-chamber endoscopy or intramural endoscopy will continue to advance. Device developments such as lumen-attached metal stents (LAMS) will further reduce their invasiveness by shifting procedures from combined laparoscopic-endoscopic approaches to purely endoscopic techniques. An example is the treatment of choledocholithiasis following gastric bypass surgery. This clinical condition that once required laparotomy and open common bile duct exploration has been routinely treated in recent years using laparoscopic access to the remaining stomach with transabdominal ERCP. It is now becoming more common to use LAMS to provide a pathway through the remaining stomach from the digestive tract so that more conventional ERCP can be offered to the patient without the need for surgery $(12,13)$. LAMS is also used as an effective and more durable alternative to cholecystostomy placement in cases of acute cholecystitis in those who are too weak to undergo cholecystectomy $(14,15)$. As we continue to seek increasingly less invasive approaches to patient care, surgery will evolve and flexible endoscope is the central platform for the next phase of our evolution as surgeons.

Endoscopic ultrasound (EUS) is an advanced endoscopic imaging technique opening new avenues of patient care that will become important in the future in surgeon-performed endoscopy and general surgery. EUS is currently a valuable imaging modality with a wide variety of diagnostic and therapeutic applications. New applications of EUS as an aid for the diagnosis and staging of GIS malignancies are constantly evolving (16). Contrast-enhanced EUS (CE-EUS) is proving useful in a variety of GIS conditions, and elastography will expand the diagnostic utility of EUS for solid lesions. EUS serves as a robust platform for therapeutic measures and will continue to increase in value for surgeons who adopt the endoscopic platform as the foundation for their future.

\section{CONCLUSION}

The surgeon's role is to keep up with innovations. The field of endoscopy largely represents surgical innovation, and we must continue to expand the utility of the flexible endoscopy platform as it lays the foundation for the future of general and gastrointestinal surgery. Surgeon-performed endoscopy is an important component of surgical practice and a set of skills that will be critical in our quest to treat patients using increasingly less invasive approaches. We are not surgical endoscopists; we are surgeons performing endoscopy and endoscopic surgery for diagnostic and therapeutic purposes. After all, the endoscope is one of our many diagnostic and therapeutic tools that are as essential as any. 
Peer-review: Externally peer-reviewed.

Conflict of Interest: No conflict of interest was declared by the authors.

Financial Disclosure: The authors declared that this study has received no financial support.

\section{REFERENCES}

1. Leger P. Antonin Jean Desormeaux. Prog Urol 2004; 14(6): 1231-8.

2. Kocher R, Sahni NR. Rethinking health care labor. N Engl J Med 2011; 365(15): 1370-2.

3. Heneghan SJ, Bordley IV J, Dietz PA, Gold MS, Jenkins PL, Zuckerman $R J$. Comparison of urban and rural general surgeons: motivations for practice location, practice patterns, and education requirements. J Am Coll Surg 2005; 201(5): 732-6.

4. Reed WP, Kilkenny JW, Dias CE, Wexner SD. A prospective analysis of 3525 esophagogastroduodenoscopies performed by surgeons. Surg Endosc 2004; 18(1): 11-21.

5. Wexner SD, Garbus JE, Singh JJ. A prospective analysis of 13,580 colonoscopies. Reevaluation of credentialing guidelines. Surg Endosc 2001; 15(3): 251-61.

6. Lee AHH, Lojanapiwat N, Balakrishnan V, Chandra R. Is there a difference in adenoma detection rates between gastroenterologists and surgeons? World J Gastrointest Endosc 2018; 10(6): 109-16.

7. Britt $L D$, Richardson JD. Residency review committee for surgery: an update. Arch Surg 2007; 142(6): 573-5.

8. Martinez J, Akpinar E, Andres Astudillo J. Use of endoscopy to prepare patients for surgery. Tech Gastrointest Endosc 2013;15:173-9.
9. Pasricha PJ, Hawari R, Ahmed I, Chen J, Cotton PB, Hawes RH, et al. Submucosal endoscopic esophageal myotomy: a novel experimental approach for the treatment of achalasia. Endoscopy 2007; 39(9): 761-4.

10. Hakansson B, Montgomery M, Cadiere GB, Rajan A, Brules des Varannes $S$, Lerhun $M$, et al. Randomised clinical trial: transoral incisionless fundoplication vs. sham intervention to control chronic GERD. Aliment Pharmacol Ther 2015; 42(11-12): 1261-70.

11. Xu MD, Cai MY, Zhou PH, Qin XY, Zhong YS, Chen WF, et al. Submucosal tunneling endoscopic resection: a new technique for treating upper Gl submucosal tumors originating from the muscularis propria layer (with videos). Gastrointest Endosc 2012; 75(1): 195-9.

12. Duan TY, Tan YY, Wang XH, Lv L, Liu DL. A comparison of submucosal tunneling endoscopic resection and endoscopic full-thickness resection for gastric fundus submucosal tumors. Rev Esp Enferm Dig 2018; 110(3): 160-5.

13. Baron TH, Song LM, Ferreira LE, Smyrk TC. Novel approach to therapeutic ERCP after long-limb Roux-en-Y gastric bypass surgery using transgastric self-expandable metal stents: experimental outcomes and first human case study (with videos). Gastrointest Endosc 2012; 75(6): 1258-63.

14. Shakhatreh MH, Yeaton P. ERCP through a gastrojejunal lumen-apposing stent. VideoGIE 2016; 1(1): 19-21.

15. Kalva NR, VanarV, Forcione D, Bechtold ML, Puli SR. Efficacy and safety of lumen apposing self-expandable metal stents for EUS guided cholecystostomy: a meta-analysis and systematic review. Can J Gastroenterol Hepatol 2018; 2018: 7070961

16. Jain D, Bhandari BS, Agrawal N, Singhal S. Endoscopic ultrasound-guided gallbladder drainage using a lumen-apposing metal stent for acute cholecystitis: a systematic review. Clin Endosc 2018; 51(5): 450-62.

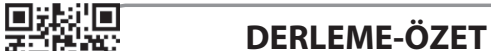

Turk J Surg 2021; 37 (2): 83-86

Cerrahide endoskopi

Ahmet Serdar Karaca, M. Mahir Özmen, Ahmet Çınar Yastı, Seher Demirer

Türk Cerrahi Derneği Yönetim Kurulu Inisiyatifi Adına

\section{ÖZET}

Son 20 yılda endoskopide önemli gelişmeler yaşanmıştır. Başlangıçta endoskopi bir tanı aracı olarak geliştirildi ve kullanıldı. Yeni teknoloji geliştikçe, bu cihazlar terapötik manevralar için de temel teşkil etti. Son yıllarda geleneksel cerrahi yaklaşımların yerini alan prosedürleri gerçekleştirmek için fleksbl endoskoplar kullanıldı. Bu alana örnek olarak transanal minimal invaziv cerrahi, doğal orifis transluminal endoskopik cerrahi, endoskopik metabolik cerrahi ve üçüncü boşluk endoskopileri gösterilebilir. Tarih boyunca cerrahlar endoskopik tekniklerin, prosedürlerin ve ekipmanın tasarımında ve geliştirilmesinde hayati bir rol oynamıştır. Cerrahlar, endoskopinin ilerlemesine öncülük etmeye, önemli katkılar sağlamaya ve innovasyon için rol modelleri olarak hizmet etmeye devam etmektedirler.
\end{abstract}

Anahtar Kelimeler: Endoskopi, perkütan endoskopik gastrostomi (PEG), endoskopik retrograd kolanjiyopankreatografi (ERCP), endoskopik ultrason (EUS), lümen takan metal stentler (LAMS), submukozal tünelleme endoskopik rezeksiyon (STER)

DOi: $10.47717 /$ turkjsurg.2021.000000576 